\section{STATISTICAL ANALYSIS OF THE HIGH POTENTIAL INCIDENT IN ANDALS OIL OF INDONESIA}

Fermi Dwi Wicaksonoa*, Udisubakti Ciptomulyonoa, Ketut Buda Artana $^{b}$, Mohammad Isa Irawanc

aDepartemen Manajemen Teknologi Fakultas Desain Kreatif dan Bisnis Digital, Institut Teknologi Sepuluh Nopember, Surabaya, Indonesia

bDepartemen Teknik Sistem Perkapalan, Fakultas Teknologi Kelautan, Institut Teknologi Sepuluh Nopember, Surabaya, Indonesia

cDepartemen Matematika, Fakultas Sains dan Analitika Data, Institut Teknologi Sepuluh Nopember, Surabaya, Indonesia
Article history

Received

16 April 2020

Received in revised form

29 November 2020

Accepted

3 December 2020

Published online

23 February 2021

*Corresponding author fermi.207032@mhs.its.ac.id

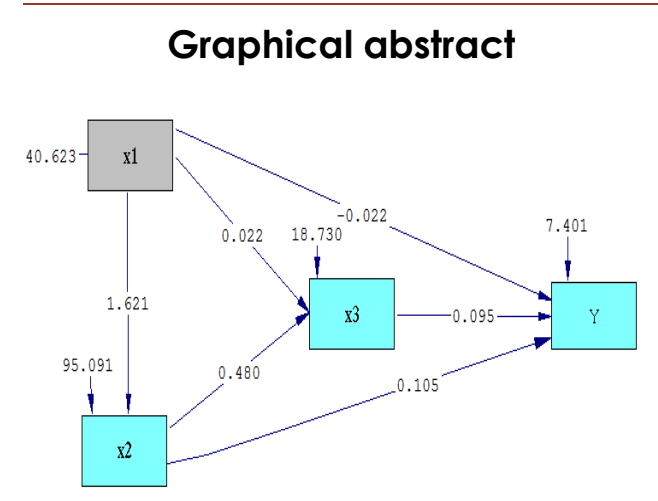

\begin{abstract}
The oil and gas industry involves latent risks which are considered as one of the most severe consequences. This circumstance mainly due to the existence of intrinsic hazards involved. As part of process safety management, past incidents analysis should be performed to eliminate the potential of significant accident occurrence. It is crucial to identify the root cause of the incidents. This research discloses the degree of importance of causal factors in contributing to an incident. The methodology based on regression analysis and path analysis is performed to identify the degree of importance of incident causes. A case study is performed at Andals Oil of Indonesia to demonstrate the most significant factor leading to an incident. As the baseline for this research, incident data are gathered from Andals Oil's database during 2006 - 2018. The statistics describe the most frequent type of incident that occurs during the oil and gas field operations. Three major root causes in the oil and gas industry are evaluated: 1. Organizational system factor; 2 . Job factor leading to unsafe working conditions; 3. Human-behavioral factor. Based on the regression analysis and path analysis, it is concluded that the number of High potential incidents is directly affected by Job factor leading to unsafe condition and Human-behavioral factor. Although the Organizational system factor may not significantly affect the number of High potential incidents, this factor still directly engenders unsafe working condition by affecting variable Job factors. Therefore, corrective and preventive action should be addressed based on the degree of importance for each incident causes factor.
\end{abstract}

Keywords: High potential incident, incident causes analysis, path analysis, process safety management, regression analysis

(C) 2021 Penerbit UTM Press. All rights reserved

\subsection{INTRODUCTION}

Learning from major incidents in the oil and gas industry are the important sources of information to prevent the occurrence of similar incidents in the future [1]. These incidents occurred mainly due to the high risk involved in oil and gas operations. The reason that incident prevention receives much attention in the oil and gas industry is that the activities associated with oil and gas extraction and processing are generally regarded as high risk in terms of consequences [2]. The oil and gas industry is 
commonly regarded as high risk due to multiple internal and external hazards that personnel working in, thereon are potentially exposed to [3]. This means that incidents occur as a result of its high-risk operation [4]. According to this condition, a minor event may rapidly escalate into catastrophic incidents. As ever occurred in the past, many incidents have led to large loss of assets and human life and tremendous damage to the environment [5]. The Richmond refinery incident is one example of how a negligible leak incident could lead to a major explosion. As described in the investigation report [6], the gas cloud, which cannot be limited either by time or quantity is the root cause of the catastrophic incident. As stated by Halim et al. [5], "It is thus essential to understand why these incidents occur to develop an awareness of the condition that we have the potential to lead to disasters." Such a kind of effort will enable preventative measures to be taken for the incidents to occur.

Over the past years, many researchers have performed several studies to determine incident causes by analyzing anomaly symptoms in the form of unsafe acts and unsafe conditions [7-11]. The researches were conducted in need of investigating incidents and near-misses to gather the information for preventing recurrences [5, 12]. Such a kind of study was performed by Christou and Konstantinidou for the European Commission Scientific and Policy Reports [13]. They analyzed incidents related to the oil and gas industry based on specific hazards, such as: fire, after ignition released hydrocarbon; explosion, after gas release; and oil release contributes to pollution on sea. Their source of research was the incident database issued by both the European government's bureau and oil and gas producers association. Skogdalen and Vinnem [1] perform the study on precursor incidents investigation and QRA in the oil and gas industry to mention what causes behind the incidents. By applying quantitative risk assessment (QRA) method, they found that the root causes of the major incidents involved both human and organizational factors, and it is a different approach to control major process incidents from occupational accidents, such as slip, trips, and falls. In conclusion, from the studies, the number of occupational incidents is not merely an indicator of major process risks, which often bring misleading assumptions $[1,14,15]$.

There are many studies performed to analyze incident causes, yet most of these are limited to specific sectors of industry or the chemical industry in general. Only a few of the research works have been done which are focused on the upstream oil and gas industry [5]. Besides, there are no specific studies performed to determine the degree of importance for a root cause in contributing to an incident. There has been no reference to determine is the most notable incident factors which can lead to undesirable events. Thus, major incidents prevention shall only be performed effectively where the most important contributing factor is determined so that that accurate measures can be taken. In short, to prevent incidents occurrence, significant contributing factors need to be analyzed and quantified. This means that prevention measures could be directly addressed to tackle the root cause of incidents, not at symptoms, leading to more effective incidents prevention [16].

Schematically, the Indonesian oil and gas companies identify significant incident causal factors by deriving incidents investigation database and, merely describe the most frequent type of incident occurrence as the dominant factor. While it is often that the type of incident, such as hydrocarbon release might be caused by different causes. For instance, corrosion at the pipeline or wellhead (Christmas tree) is the most contributing factor for a gas leak in one particular company. In contrast, the other company deals with insufficient system to perform hydrocarbon isolation during maintenance. In such practices, the incident causes analysis is not comprehensive to determine what is the most significant root causes and their degree of importance.

As the baseline for this research, incidents data is gathered from Andals Oil's database during 2006 2018. This paper demonstrates the development of regression analysis and path analysis as statistical review of the High potential incidents in the Indonesian oil and gas production field. This paper, hence, demonstrates comprehensive incident causes evaluation of the Indonesian Oil and Gas Company in determining which of the most dominant factor lead to major incidents.

\subsection{METHODOLOGY}

This paper demonstrates a methodology to evaluate incident causes factors which are divided into two phases. In the first phase, incidents data is gathered and analyzed to determine what causes factors contributing to the incidents during Andals Oil operation from 2006 to 2018 . This analysis will be the input to the statistical review of factors for determining oil and gas incident causes. The second phase is concerned with the statistical analysis using regression analysis and path analysis. The research framework is illustrated in Figure 1.

\subsection{High Potential Incident (HIPO)}

According to the International Oil and Gas Producer (IOGP) [17], high potential incidents (HIPOs) are defined to be any incident or near-miss that could, in other circumstances, have realistically resulted in one or more fatalities. The High potential incidents are often described as any incidents which could potentially result in catastrophic and disastrous consequences irrespective of the actual severity. This means High potential incidents could rapidly escalate to the higher consequence incidents. Skogdalen and Vinnem [1] define that High potential 
incidents are precursor incidents which indicate failure in systems controlling the risks from major hazard, and they should be thoroughly investigated in order to prevent them from reoccurring. The incidents categorized as High potential incidents are [4]: (1) Explosion (flash, detonation, deflagration); (2) Fire whether or not they are controlled quickly in a hazardous area [18]; (3) Significant and Major (Tier-1 and Tier-2) Hydrocarbon leaks [19]; (4) Emergency shutdown caused by the confirmed detection of gas leak or fire; (5) Incidents involving personnel Caught In, Under or Between; (6) Falls from height or person slips and trips (at the same height); (7) Falling objects capable of causing a fatality; (8) Incident involving confined space working [20].

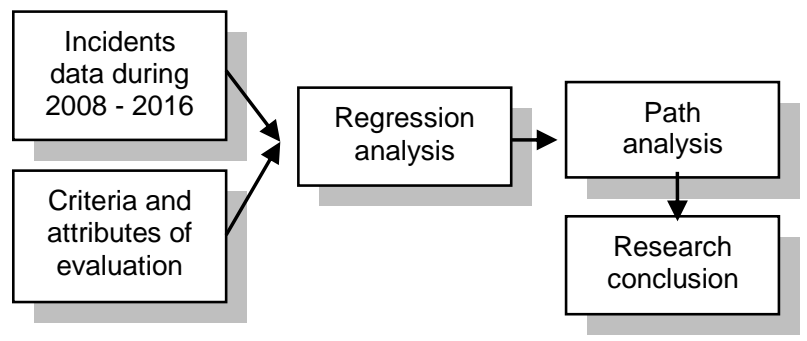

Figure 1 Research framework

During the operation, Andals Oil has experienced several High potential incidents. According to the company regulation, High potential incidents are required in-depth investigation by using a method called root cause analysis. The incidents root cause then entered into Company incidents database which can be accessed through intranet application. Andals Oil recognizes High potential incidents are all incidents that result in potential severity in level-4 (catastrophic), and level-5 (disastrous), regardless of their actual severity. The level of incidents severity and probability is described in the example of a risk matrix, as shown in Figure 2.

\subsection{Incident Investigation and Root Cause Analysis}

Incident investigation and root cause analysis are the main section of the Occupational Safety and Health Administration (OSHA) elements of process safety management [21]. Sutton [22] defines that incident investigation is emphasized because of the importance of process safety management, of which an incident investigation and analysis constitutes one element, has been in place in many cases for more than 20 years. To reveal the actual contributing factors of incidents, root cause analysis is performed by systematic safety and reliability analysis tool that proceeds deductively from the incident's occurrence [23].
During its operation, Andals Oil implements root cause analysis (RCA) to investigate High potential incidents and recordable injury accidents and formulate the corrective action plan to prevent a recurrence. RCA is developed by building a series of questions and implied fact-finding, which is directly caused in a series of tree. The serial questions raised are: (1) What is required to make the event?; (2) Are the contributing factors essential to make the event?; (3) Are the contributing factors sufficient to make the event?

\subsection{Andals Oil Incidents Statistics}

Information regarding incidents analysis in Andals Oil is available in the Company database application. The database contains incidents, anomaly, and near-misses that occurred in Andals Oil from January 2006 until September 2018. High potential incidents are listed in the database. It is demonstrated 615 High potential incidents investigations conducted by the Company investigation boards. The High potential incidents statistics are described as "key type of event," immediate cause, and analyzed root cause. All High potential incidents are investigated using the root cause analysis method.

As in many upstream oil and gas companies, Andals Oil operations are divided into several disciplines and entities. All of the incident investigations are classified according to the concerned discipline. The explanations of those entities are:

1. Production: the primary operations entity which performs extraction of hydrocarbon by operating production facilities.

2. Well Servicing: perform hydrocarbon well intervention by using compact work over tools such as slick line, electric line, snubbing unit, and coil tubing.

3. Logistics: perform supporting operation of logistics, warehouse, and material delivery by using land, air, and marine transportation.

4. Exploration: the operation of searching and determining location of hydrocarbon reservoir. This operation includes seismic, data acquisition, and geographical survey.

5. Drilling: development of new hydrocarbon well by using drilling rigs in offshore and swamp area operation.

6. Construction: the operation of constructing platforms, pipelines, vessels, and production facilities. This operation includes greenfield projects and brownfield projects development.

7. General services: any other supporting operation such as telecommunication, administrative works, and general cleaning and housekeeping. 


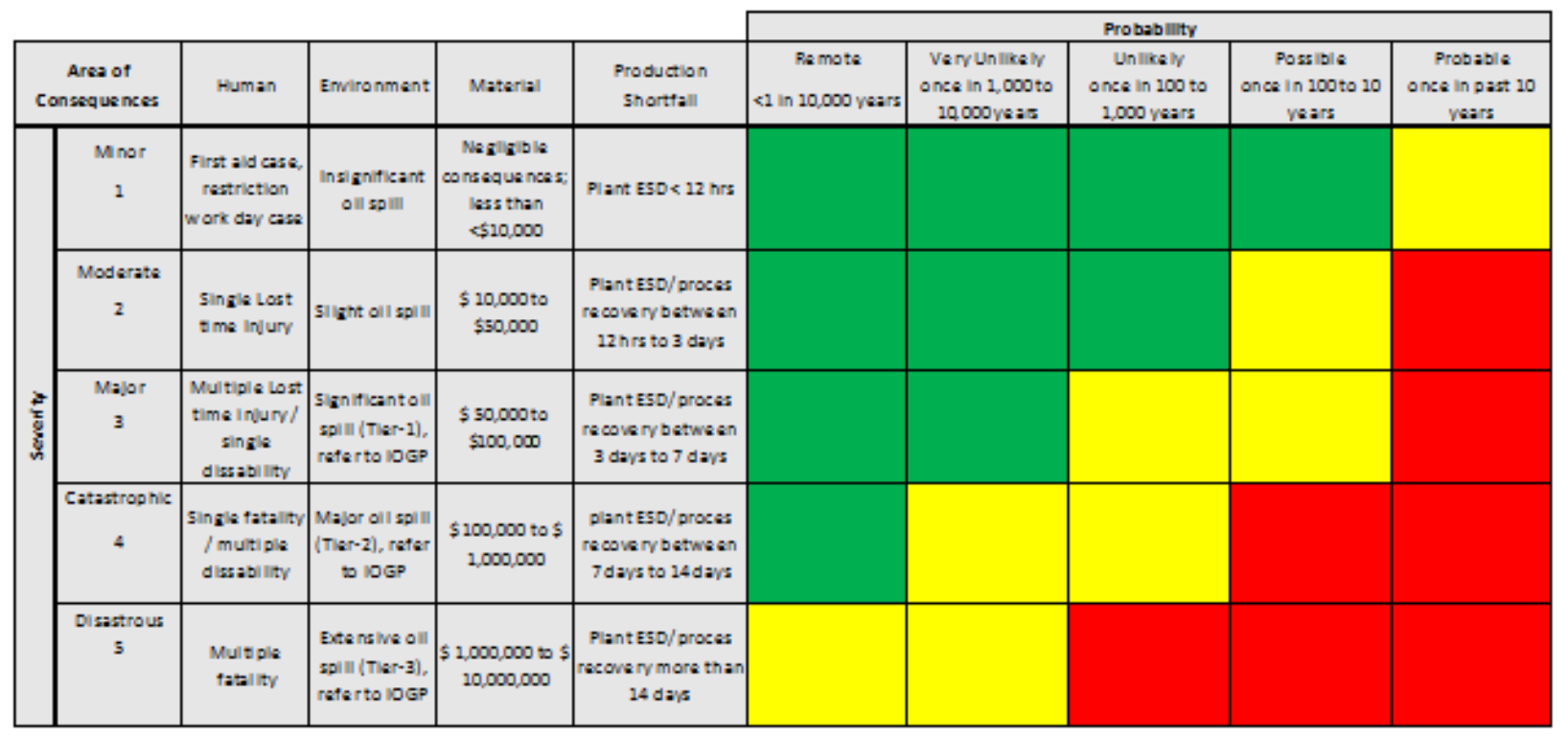

Figure 2 Example of risk matrix. It defines the terminology of risk consequences and probability of incidents. (Source: process risk and reliability management, Ian Sutton, 2015)

As demonstrated in Figure 3, production entity contributes the highest number of High potential incidents, 235 HIPOs had occurred in their operation. Followed by logistics entity in the second place, 169 HIPOs had occurred during their support activities for Andals Oil operations entity. This graphical statistics elaborates that production, as the main operation entity, possesses the highest risk among other disciplines.

High potential incidents

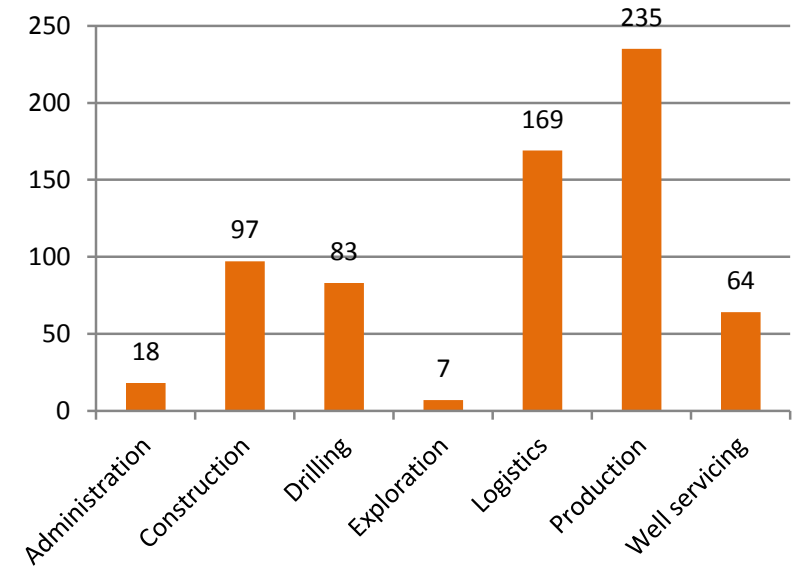

Figure 3 Number of High potential incidents occurred at the respective concern disciplines

All High potential incidents listed in the Company database are categorized according to their principal type of events, those are subsea diving incidents, production/process upset, natural event, man overboard, land transportation event, handling/lifting, explosion-fire-flash, and air transportation event. Figure 4 shows the number of incidents types provided by the company database. Each High potential incident is listed as single key type of event in general, except several HIPOs (seven cases) which are categorized as multiple key types of event, such as leak-hydrocarbon release and production/process upset; leak-hydrocarbon release and equipment failure, breakage; and leakhydrocarbon release and Explosion, fire, flash.

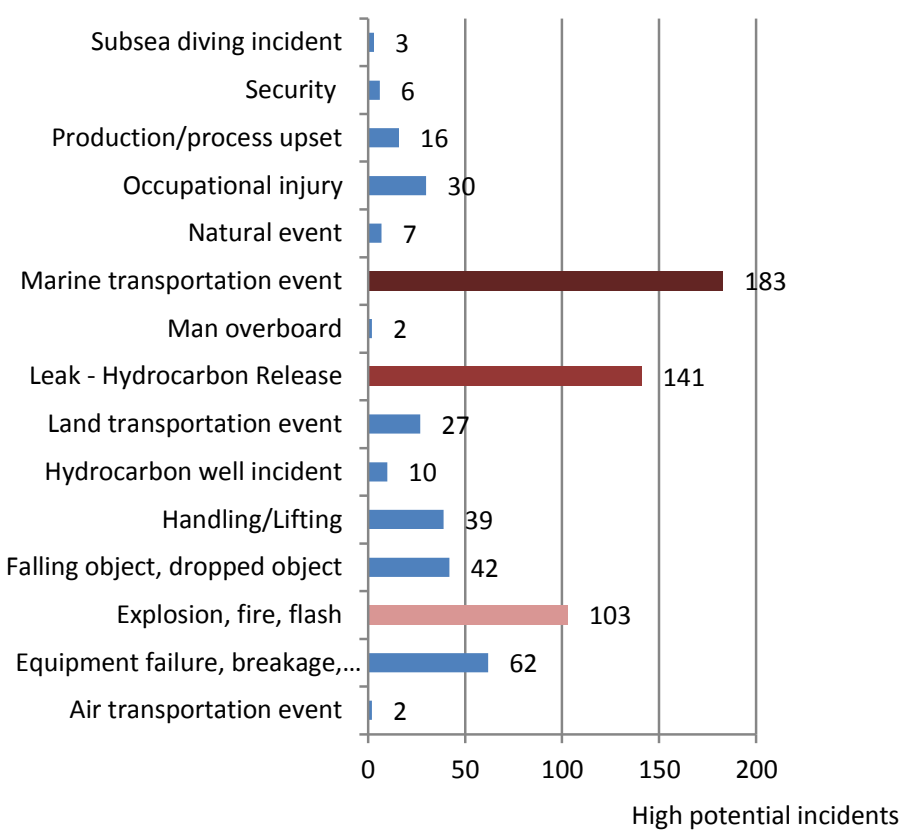

Figure 4 High potential incidents occurrence based on their key type of events

According to graphical findings in Figure 4 , it is described that marine transportation events contribute the most numerous HIPOs (27.19\%) occurrence. This is because marine transportation events HIPOs are included logistics supporting operation, and Andals Oil mainly operates their 
facilities at offshore remote location. Leakhydrocarbon release incidents come up as the second most investigated (20.95\%), followed with explosion, fire, flash incidents in the third place (15.3\%). Explosion, fire, flashes and hydrocarbon release incidents are intrinsically indicated in production concern discipline. The other critical type of incidents such as equipment failure, breakage, malfunctioning, and production/process upset are also taken place in the production field, whereas falling object and handling/lifting incidents mainly occur in the logistics operation.

\subsection{Incident Investigation Findings}

The incidents investigation results found 26 immediate causes and 25 root causes which are examined as contributing factor for the High potential incidents. The immediate causes appear as the direct factor leading to the incident occurrence. Figure 5, the cause tree analysis (CTA) investigation of hydrocarbon leakage incidents, demonstrates the immediate cause as fact-finding: "manual wing valve has been eroded" and "emergency shutdown failure." This analysis infers that the "significant hydrocarbon release incident" requires "erosion at the manual wing valve" and "emergency shutdown failure" to occur. Immediate causes could be determined at the early stages of incidents investigation. Current analysis categorizes immediate causes as unsafe condition factor and unsafe working condition. The complete result of immediate causes analysis is shown in Figure 5.

In addition, failed to comply with procedure or instruction is revealed as the second most important immediate cause to High potential incidents. It is notified that 'failed to comply with procedure or instruction' as unsafe actions, which is directly causing incidents. This immediate cause was found during the case of gas release due to failure of operating manual wing valve to ramp up the well. As clearly stated in procedure, ramp up the well can only be performed by operating wellhead choke with specified time sequence. Well intervention operators may choose to operate manual wing valve instead of wellhead choke because it will reduce time performance and it is considered as taking shortcut.

Root causes are identified as basic contributing factor leading to High potential incidents. Root causes are often classified as the initial causes which are forms as causal chain factor. This means that root causes are hidden factor which need to be eliminated through problems solving methods. Correct and adequate action plan based on proper analysis should be developed to overcome the root causes. Failure to investigate the root cause may result ineffective incidents prevention. Figure 6 elaborates the detail result of root cause analysis.

Based on the incident investigation and root cause analysis method it is found 25 contributing incidents factor identified as the root causes. From the 25 contributing factors, the root causes are classified into three categories, namely (1) Organizational system factor; (2) Job factor leading to unsafe working condition; and (3) Humanbehavioral factor. Figure 6 shows the detail information regarding the investigated root causes. As in many High potential incidents, one root cause is possible to link with the other type of root causes, e.g. failure to perform preventive maintenance based on correct frequency (job factor leading to unsafe working condition) is correlated to the existence of monitoring, audit, and inspection problems (organizational system factor). Correct incident investigation should properly address important facts that led to substantial causative factor. For example, as Halim et al. [5] mentions that "there were many investigations that stopped at reporting that the procedure was violated, but did not ask further, such as asking the person why he had deviated". Contributing incidents factor related to human error appeared mostly correlated to organizational systems that were not tackled on time [5].

From Figure 6, it is known that incidents, where job factor leading to unsafe working condition have occurred, are from the failure to manage equipment properly $(20.07 \%)$. These failures have been identified as the most prominent factor leading to High potential incidents. Equipment management failure is including failing to perform maintenance, failing inspection method or corrosion control, inadequate equipment and use of planning, and failing of equipment lifetime control. The second largest factor is related to the inadequacy of leadership and supervision (11.95\%). The findings related to this factor based the analysis are insufficient of monitoring critical job, inadequate of planning/organization, failing to provide pre-job meeting, and providing wrong, confusion instruction.

The third most significant factor is related to the failure of risk management. This finding is crucial because managing risk properly is the fundamental of process safety management. In one of HIPO case, it is investigated that the risk of $\mathrm{H}_{2} \mathrm{~S}$ presence was not identified so that the workers were not aware of the hazards. During preparation for internal inspection of slug catcher, suddenly white fumes were observed from the upper manhole, and then the gas detector detected 200 ppm $\mathrm{H}_{2} \mathrm{~S}$ and lower oxygen level. Important fact findings revealed that pyrophoric risk was not identified on the work permit neither the operating procedure for manhole opening as it never happens before on previous internal cleaning work [4]. Overall, failures of risk management factors are listed as inadequacy to evaluate risk prior to critical job, failure to evaluate risk prior to modification, and insufficient assessment of operational readiness.

The other prominent factor related to the High potential incidents is Human-behavioral factor. Figure 6 demonstrates that $8.06 \%$ of High potential incidents are caused by lack of personnel's skill and knowledge to perform their task. From the 
investigation, it is found that this finding is closely related to the complex operation with limited qualified personnel. In several cases, it is found that personnel have inadequate competence for the assigned task. In the case that involving crew-boat collision with platform piles, the driver was new personnel who did not aware of the marine route. Almost $7.97 \%$ High potential incidents were resulted from abuse, bad behavior, and ignorance of Health, safety, and environment (HSE) rules. It can be seen that this finding had arisen from the ignorance of safety culture, and often involving local contractors. Some of the cases are lack of discipline and taking shortcuts, hasty work execution, violation of safety rules or not using personal protective equipment (PPE) properly, and ignoring HSE warning.

\subsection{Data Validity Test}

The input data source from the Andals Oil's database needs to be tested to ensure the statistical analysis is based on valid data. For this purpose, statistical data validity test are performed using SPSS 24 software. Statistical Pearson moment is performed to investigate the data validity. The result of data validity test is written in Table 1.

The analysis results are concluded as valid when the significance value (Sig. 2-tailed) is less than 0.05 according to the total variable. From Table 1, all significance values (Sig. 2-tailed) are less than 0.05 Therefore, all variables data are valid.

Table 1 The result of Pearson moment validity test

\begin{tabular}{|c|c|c|c|c|c|}
\hline & & $\begin{array}{l}\text { Human } \\
\text { factor }\end{array}$ & $\begin{array}{l}\text { Job } \\
\text { factor }\end{array}$ & $\begin{array}{l}\text { Org. } \\
\text { system } \\
\text { factor }\end{array}$ & Total \\
\hline \multirow[t]{3}{*}{$\begin{array}{l}\text { Human } \\
\text { factor }\end{array}$} & $\begin{array}{c}\text { Pearson } \\
\text { correlation }\end{array}$ & 1 & $.848^{* *}$ & $.624^{* *}$ & $.728^{* *}$ \\
\hline & $\begin{array}{l}\text { Sig. (2- } \\
\text { tailed) }\end{array}$ & & 0.000 & 0.000 & 0.000 \\
\hline & $N$ & 134 & 134 & 134 & 134 \\
\hline \multirow[t]{3}{*}{$\begin{array}{l}\text { Job } \\
\text { factor }\end{array}$} & $\begin{array}{r}\text { Pearson } \\
\text { correlation }\end{array}$ & $.848^{* *}$ & 1 & $.727^{* *}$ & $.480 * *$ \\
\hline & $\begin{array}{l}\text { Sig. (2- } \\
\text { tailed) }\end{array}$ & 0.000 & & 0.000 & 0.000 \\
\hline & $\mathrm{N}$ & 134 & 134 & 134 & 987 \\
\hline \multirow{3}{*}{$\begin{array}{l}\text { Org. } \\
\text { system } \\
\text { factor }\end{array}$} & $\begin{array}{c}\text { Pearson } \\
\text { correlation }\end{array}$ & $.624^{* *}$ & $.727^{* *}$ & 1 & $.772^{* *}$ \\
\hline & $\begin{array}{l}\text { Sig. (2- } \\
\text { tailed) }\end{array}$ & 0.000 & 0.000 & & 0.000 \\
\hline & $\mathrm{N}$ & 134 & 134 & 134 & 134 \\
\hline \multirow[t]{3}{*}{ Total } & $\begin{array}{r}\text { Pearson } \\
\text { correlation }\end{array}$ & $.728^{* *}$ & $.480^{* *}$ & $.772^{* *}$ & 1 \\
\hline & $\begin{array}{l}\text { Sig. (2- } \\
\text { tailed) }\end{array}$ & 0.000 & 0.000 & 0.000 & \\
\hline & $\mathrm{N}$ & 134 & 134 & 134 & 134 \\
\hline
\end{tabular}

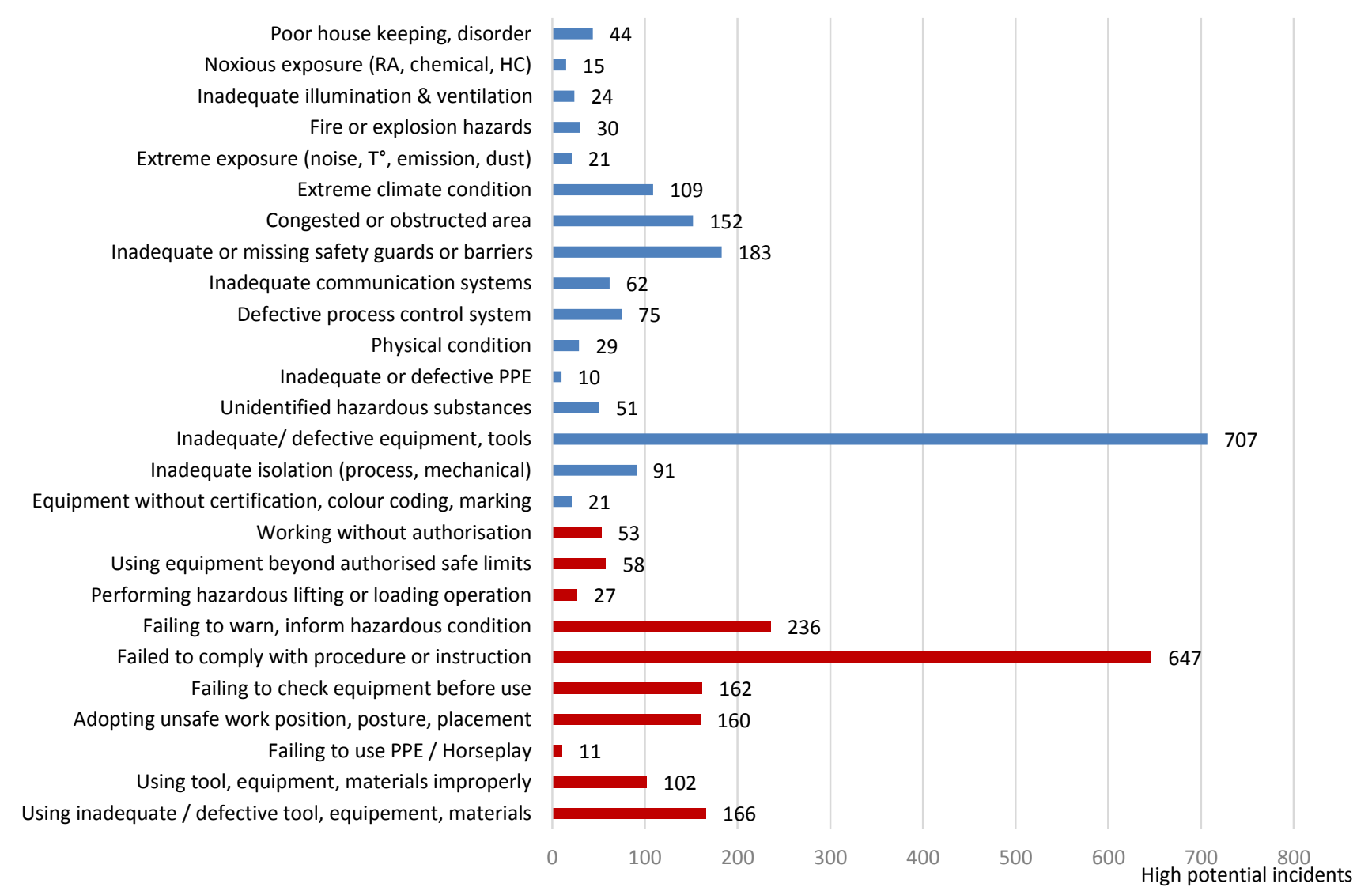

Figure 5 Direct contributing factors appears as immediate factors to the High potential incidents. The blue color indicaites unisafe working condition, and the red color indicates unsafe human actions 


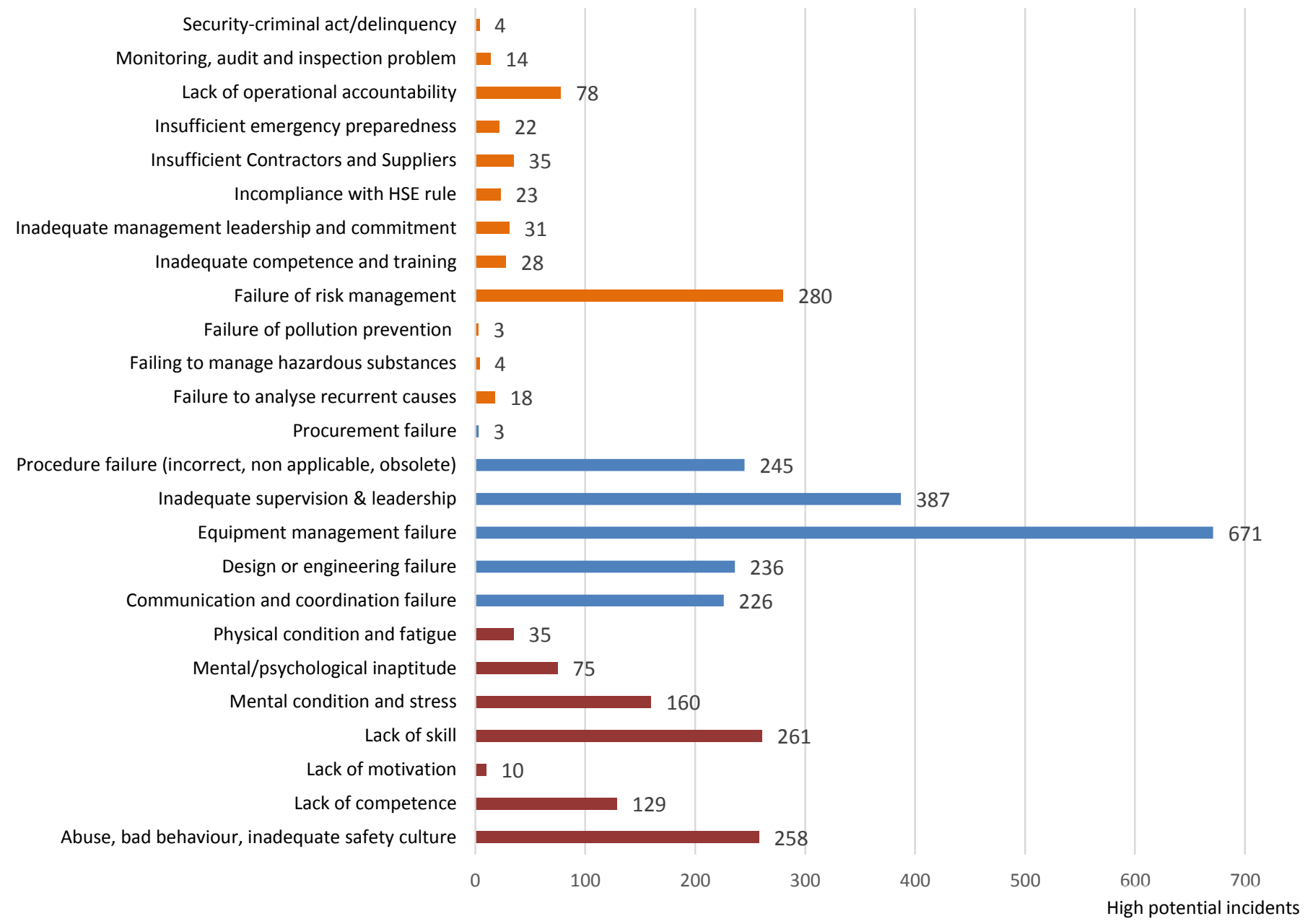

Figure 6 Figure showing basic contributing factors that appear as root cause factors to the High potential incidents. Dark green color indicates the Human-behavioral factor, light blue color indicates the Job factor leading to unsafe working condition, and orange color defines the Organizational system factor

\subsection{RESULT AND DISCUSSION}

This section presents the research analysis result and discussion towards the problem stated in the introduction. Before we start the statistical analysis, we should state the degree of confidence and the confidence interval for all variables. In this paper, we use the degree of confidence of $95 \%$ as the baseline for all statistical analyses. The confidence interval is obtained by performing one sample t-test for all the variables using SPSS 24 software as illustrated in table 2.

\subsection{Pearson Correlation Analysis}

Pearson correlation analysis is statistical theory which has been widely used to measure relationship and linear dependence between two random variables [24]. This paper presents three variables assessed by the Pearson correlation analysis in correspond to the High potential incident. This work is aimed to measure the statistical correlation of one incident root cause from another one.

The results of Pearson correlation analysis are described by the SPSS 24 software as written in Table 1 , and the scatterplot diagrams is demonstrated in Figure 7, Figure 8 and Figure 9.

Table 2 The result of one-sample t-test

\begin{tabular}{|c|c|c|c|c|c|c|}
\hline & \multicolumn{6}{|c|}{ Test Value $=0$} \\
\hline & \multirow[b]{2}{*}{$t$} & \multirow[b]{2}{*}{ df } & \multirow{2}{*}{$\begin{array}{l}\text { Sig. (2- } \\
\text { tailed) }\end{array}$} & \multirow{2}{*}{$\begin{array}{c}\text { Mean } \\
\text { Difference }\end{array}$} & \multicolumn{2}{|c|}{$\begin{array}{l}95 \% \text { Confidence } \\
\text { Interval of the } \\
\text { Difference }\end{array}$} \\
\hline & & & & & Lower & Upper \\
\hline$x 1$ & 13.389 & 133 & 0.000 & 1.76119 & 1.5010 & 2.0214 \\
\hline$x 2$ & 10.006 & 133 & 0.000 & 1.00000 & 0.8023 & 1.1977 \\
\hline$x 3$ & 12.904 & 133 & 0.000 & 1.58955 & 1.3459 & 1.8332 \\
\hline
\end{tabular}




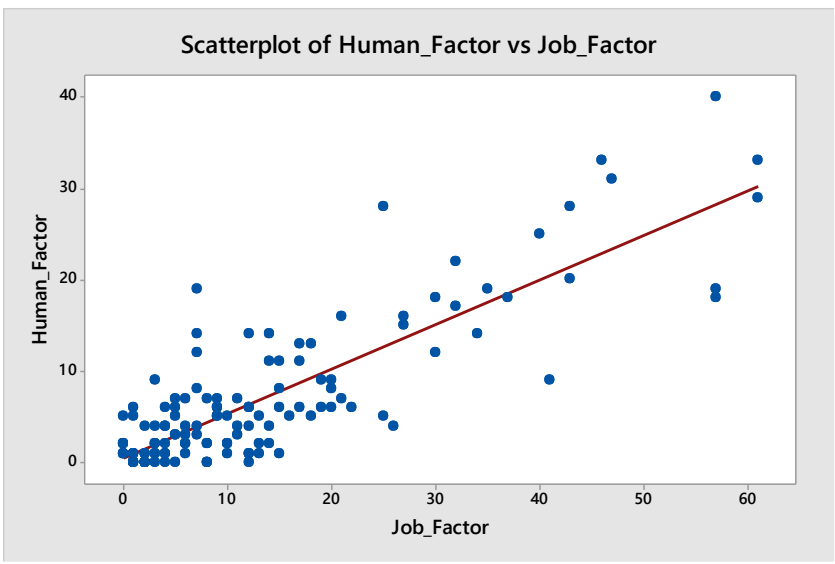

Figure 7 Scatter plot graphic between variables Human factor versus Job factor

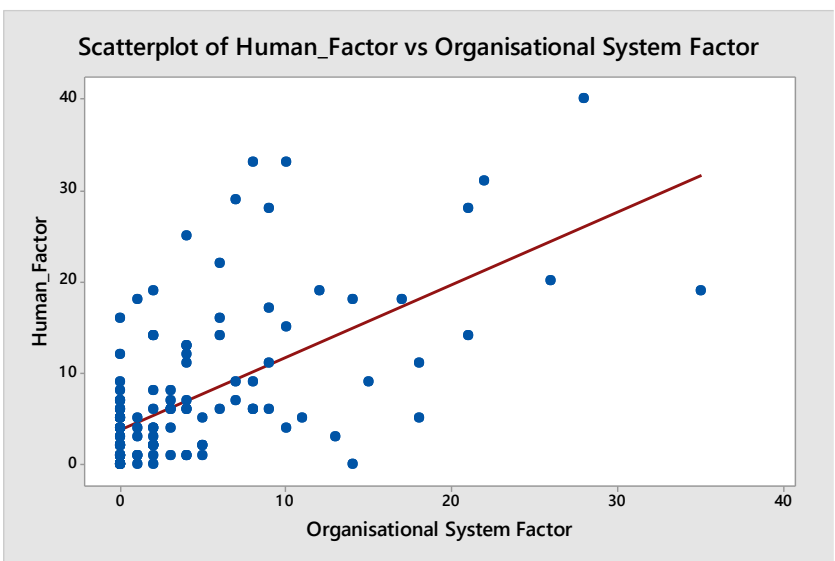

Figure 8 Scatter plot graphic between variables Human factor versus Organizational factor

Table 3 Pearson correlation analysis for high potential incident root causes

\begin{tabular}{|c|c|c|c|c|}
\hline & & $\begin{array}{l}\text { Human } \\
\text { factor }\end{array}$ & $\begin{array}{l}\text { Job } \\
\text { factor }\end{array}$ & $\begin{array}{l}\text { Org. } \\
\text { system } \\
\text { factor }\end{array}$ \\
\hline \multirow[t]{3}{*}{$\begin{array}{l}\text { Human } \\
\text { factor }\end{array}$} & $\begin{array}{l}\text { Pearson } \\
\text { correlation }\end{array}$ & 1 & $.848^{* *}$ & $.624^{* *}$ \\
\hline & Sig. (2-tailed) & & 0.000 & 0.000 \\
\hline & $\mathrm{N}$ & 134 & 134 & 134 \\
\hline \multirow[t]{3}{*}{$\begin{array}{l}\text { Job } \\
\text { factor }\end{array}$} & $\begin{array}{l}\text { Pearson } \\
\text { correlation }\end{array}$ & $.848^{* *}$ & 1 & \\
\hline & Sig. (2-tailed) & 0.000 & & 0.000 \\
\hline & $N$ & 134 & 134 & 134 \\
\hline \multirow{3}{*}{$\begin{array}{l}\text { Org. } \\
\text { system } \\
\text { factor }\end{array}$} & $\begin{array}{l}\text { Pearson } \\
\text { correlation }\end{array}$ & $.624^{* *}$ & $.727^{* *}$ & 1 \\
\hline & Sig. (2-tailed) & 0.000 & 0.000 & \\
\hline & $\mathrm{N}$ & 134 & 134 & 134 \\
\hline
\end{tabular}

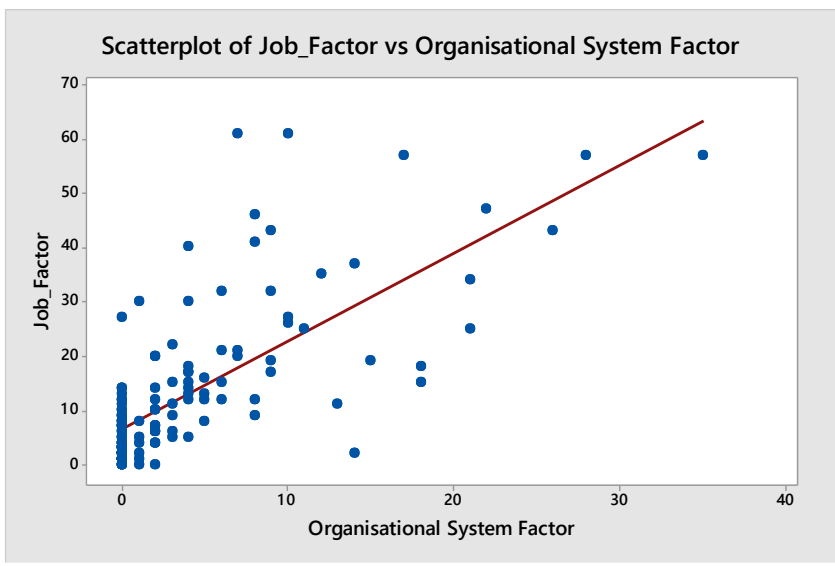

Figure 9 Scatter plot graphic between variables Job factor versus Organizational system factor

It is identified that Pearson correlation coefficient shows the highest relationship between Job factor leading to unsafe working condition and Humanbehavioral factor (0.848). The most significant interdependent variables are identified between those two variables. It means that contributing factor lead to High potential incidents caused by Job factor is also caused by Human-behavioral factor. The relationship between two variables is influencing each other.

\subsection{Multiple Predictor Regression Analysis}

The regression analysis is performed to identify the influence effect from the dependent variable (predictor) to the independent variable (criterion). The regression analysis in this research is aimed to investigate variable relationship from the root cause to the High potential incident occurrence. The variables (predictor and criterion) implicated in the regression analysis are written hereunder.

Predicator:

$x_{1}=$ Organizational system factor

$x_{2}=$ Job factor leading to unsafe working condition

$x_{3}=$ Human/behavioral factor

Criterion:

$Y=$ High potential incident occurence

As defined by Pearson correlation analysis, the strongest relationship relies between $x_{2}$ and $x_{3}$. Therefore, the regression analysis is firstly performed based on their causal effect to the High potential incident. The regression equation is written as mathematical model.

$$
Y=\beta_{0}+\beta_{2} x_{2}+\beta_{3} x_{3}+\varepsilon
$$

From Table 4, it is identified the regression coefficient. The linear equation of regression analysis for multiple predictor $x_{2}$ and $x_{3}$, is written as: 


$$
Y=3.276+0.098 x_{2}+0.095 x_{3}
$$

From the analysis shown in Table 3 , this research identifies the statistical values of $x_{2}$ namely, $t_{\text {value }}=$ 3.105 ,

$p_{\text {value }}=\frac{0.002}{2}=0.001 \rightarrow p_{\text {value }}<0.05($ right tailed test $)$,

which means variable Job factor $\left(x_{2}\right)$ is positively influential to variable Number of High potential incident $(Y)$. The statistical values of $x_{3}$ are, $t_{\text {value }}=$ 1.724 ,

$p_{\text {value }}=\frac{0.087}{2}=0.043 \rightarrow p_{\text {value }}<0.05$ (right tailed test $)$.

This means that variable Human factor $\left(x_{3}\right)$ are positively influential to variable Number of High potential incident $(Y)$.

Table 4 Regression coefficients table between $x_{2}$ and $x_{3}$

\begin{tabular}{ccccccc}
\hline \multirow{2}{*}{ Model } & \multicolumn{2}{c}{$\begin{array}{c}\text { Unstandardized } \\
\text { coefficients }\end{array}$} & $\begin{array}{c}\text { Standardized } \\
\text { coefficients }\end{array}$ & $\boldsymbol{t}$ & Sig. \\
\cline { 3 - 7 } & & B & $\begin{array}{c}\text { Std. } \\
\text { Error }\end{array}$ & Beta & & \\
\hline 1 & (Constant) & 3.276 & 0.325 & & 10.082 & 0.000 \\
& x2 & 0.098 & 0.032 & 0.406 & 3.105 & 0.002 \\
& x3 & 0.095 & 0.055 & 0.225 & 1.724 & 0.087
\end{tabular}

Table 5 Analysis of variance (ANOVA) of variable $x_{2}$ and $x_{3}$

\begin{tabular}{llllll}
\hline Model & $\begin{array}{c}\text { Sum of } \\
\text { squares }\end{array}$ & df & $\begin{array}{c}\text { Mean } \\
\text { square }\end{array}$ & F & Sig. \\
\hline 1 Regression & 579.721 & 2 & 289.860 & 38.528 & $.000^{\mathrm{b}}$ \\
Residual & 985.563 & 131 & 7.523 & & \\
Total & 1565.284 & 133 & & & \\
\hline
\end{tabular}

The significance test for multiple predictor regression is performed by demonstrating ANOVA table from the SPSS 24 software. From the analysis written in Table 5, statistical values are stated: $F_{\text {value }}=$ 38.528 and $p_{\text {value }}=0.000 \rightarrow p_{\text {value }}<0.05$. Based on this analysis, variable $x_{2}$ and $x_{3}$ are linearly correlated to the variable (Y). It is inferred that there is simultaneous influent effect of variables Job factor and Human factor to Number of High potential incident variables.

It is known that the value of regression coefficient illustrates the degree of importance for each predictor to the criterion. Therefore, it is necessary to identify which variable gives the highest influence to the High potential incident occurrence. Partial correlation analysis is performed to identify respective leverage of variable $x_{2}$ and $x_{3}$ in regards to variable $Y$.

Based on the partial correlation analysis, it is obtained the value of partial correlation coefficient respectively,
1. Partial correlation between variables $x_{2}$ and $Y$ by controlling variables $\mathrm{x}_{3}:\left(r_{23}\right)=0.262$ and $p_{\text {value }}=$ $0.002 \rightarrow p_{\text {value }}<0.05$ (Table 6). Based on these values, correlation coefficient between $x_{2}$ and $Y$ is significant. This means that although variable $x_{3}$ is well controlled, the leverage effect cause by $x_{2}$ remains significant to variable $Y$. Job factor leading to unsafe condition variable is still affecting the number of High potential occurrence.

2. Partial correlation between variables $x_{3}$ and $Y$ by controlling variables $\mathrm{x}_{2}:\left(r_{32}\right)=0.149$ and $p_{v a l u e}=$ $0.087 \rightarrow p_{\text {value }}>0.05$ (Table 7). Based on these values, correlation coefficient between $x_{3}$ and $Y$ is not significant. It is inferred that variable $x_{3}$ has no significant impact when variable $x_{2}$ is controlled significantly to the variable $Y$.

Table 6 Partial correlation analysis variables $x 2$ and $Y$ by controlling variable $\times 3$

\begin{tabular}{|c|c|c|c|c|}
\hline \multicolumn{3}{|c|}{ Control variables } & \multirow{2}{*}{$\frac{\mathbf{Y}}{1.000}$} & \multirow{2}{*}{$\begin{array}{c}\mathbf{x 2} \\
0.262 \\
0.002\end{array}$} \\
\hline$\times 3$ & Y & $\begin{array}{l}\text { Correlation } \\
\text { Significance } \\
\text { (2-tailed) }\end{array}$ & & \\
\hline & & df & 0 & 131 \\
\hline & $x 2$ & $\begin{array}{l}\text { Correlation } \\
\text { Significance } \\
\text { (2-tailed) }\end{array}$ & $\begin{array}{l}0.262 \\
0.002\end{array}$ & 1.000 \\
\hline & & df & 131 & 0 \\
\hline
\end{tabular}

Table 7 Partial correlation analysis variables $x 3$ and $Y$ by controlling variable $x 2$

\begin{tabular}{|c|c|c|c|c|}
\hline \multicolumn{3}{|c|}{ Control variables } & \multirow{2}{*}{$\frac{\mathbf{Y}}{1.000}$} & $\frac{x 3}{0.149}$ \\
\hline$x 2$ & $Y$ & $\begin{array}{l}\text { Correlation } \\
\text { Significance } \\
\text { (2-tailed) }\end{array}$ & & $\begin{array}{l}0.149 \\
0.087\end{array}$ \\
\hline & & df & 0 & 131 \\
\hline & $x 3$ & $\begin{array}{l}\text { Correlation } \\
\text { Significance } \\
\text { (2-tailed) }\end{array}$ & $\begin{array}{l}0.149 \\
0.087\end{array}$ & 1.000 \\
\hline & & df & 131 & 0 \\
\hline
\end{tabular}

The degree of importance between variables is marked by the partial correlation coefficient value. Therefore, variable $x_{2}\left(r_{23}=0.262\right)$ is more significant than variable $x_{3}\left(r_{32}=0.149\right)$ in correspondent to the High potential incident causes.

Multiple predictor regression analysis is also performed for the second strongest relationship between variables, $x_{1}$ and $x_{2}$. This research develops the mathematical equation for this regression analysis as follow:

$$
Y=\beta_{0}+\beta_{1} x_{1}+\beta_{2} x_{2}+\varepsilon
$$


And the statistical values of $x_{1}$ are given as, $t_{\text {value }}=$ $-0.372 \quad, \quad p_{-}$value $=0.711 / 2=0.355 \rightarrow p_{-}$value $>$ 0.05 (right tailed test).

This means that variable Organizational system factor $\left(x_{1}\right)$ is not positively influential to variable Number of High potential incident $(Y)$. Whereas, the statistical values of $x_{2}$ are given as, $t_{\text {value }}=6.116$, $p_{-}$value $=0.000 / 2=0.000 \rightarrow p_{-}$value $<$ 0.05 (right tailed test).

This means that variable Job factor $\left(x_{2}\right)$ is positively influential to variable Number of High potential incident. The regression analysis in this section demonstrates the simultaneous leverage effect which is caused by variable $x_{1}$ and $x_{2}$ towards variable $Y$. Table 9 elaborates the results.

Table 8 Regression coefficients table between $x_{1}$ and $x_{2}$

\begin{tabular}{ccccccc}
\hline \multirow{2}{*}{ Model } & \multicolumn{2}{c}{$\begin{array}{c}\text { Unstandardized } \\
\text { coefficients }\end{array}$} & $\begin{array}{c}\text { Standardized } \\
\text { coefficients }\end{array}$ & $t$ & Sig. \\
\cline { 2 - 5 } & B & $\begin{array}{c}\text { Std. } \\
\text { error }\end{array}$ & Beta & & \\
\hline 1 & (Constant) & 3.319 & 0.328 & & 10.133 & 0.000 \\
& x1 & -0.020 & 0.055 & -0.038 & -0.372 & 0.711 \\
& & 0.151 & 0.025 & 0.624 & 6.116 & 0.000 \\
\hline
\end{tabular}

Based on the statistical values on Table 8, this research elaborates linear regression equation for $x_{1}$ and $x_{2}$.

$$
Y=3.319-0.020 x_{1}+0.151 x_{2}
$$

Table 9 Analysis of variance (ANOVA) of variable $x_{1}$ and $x_{2}$

\begin{tabular}{lrrrrr} 
Model & $\begin{array}{c}\text { Sum of } \\
\text { squares }\end{array}$ & df & $\begin{array}{c}\text { Mean } \\
\text { square }\end{array}$ & F & Sig. \\
\hline 1 Regression & 558.431 & 2 & 279.216 & 36.328 & $.000^{\mathrm{b}}$ \\
Residual & 1006.852 & 131 & 7.686 & & \\
$\quad$ Total & 1565.284 & 133 & & & \\
\hline
\end{tabular}

The statistical values in Table 9 demonstrate: $F_{\text {value }}=36.328$ and $p_{\text {value }}=0.000 \rightarrow p_{\text {value }}<0.05$. Based on this analysis, variable $x_{1}$ and $x_{2}$ are linearly correlated to the variable $(Y)$. Based on this analysis, there is simultaneous leverage effect caused by variables Organizational system factor and Job factor to the variable Number of High potential incident occurrence.

It is necessary to investigate the leverage effect caused by respective variables. This analysis is intended to identify the highest affecting predictor variables to the criterion variable $Y$.

From the statistical values stated in Table 10 and 11 , it is inferred that:
1. Partial correlation between variables $x_{1}$ and $Y$ by controlling variables $x_{2}$ : $\left(r_{12}\right)=-0.032$ and $p_{\text {value }}=$ $0.711 \rightarrow p_{\text {value }}>0.05$. Based on these values, correlation coefficient between $X_{1}$ and $Y$ is not significant. It is inferred that variable $x_{1}$ has no significant impact when variable $x_{2}$ is controlled significantly to the variable $Y$.

2. Partial correlation between variables $x_{2}$ and $Y$ by controlling variables $\mathrm{x}_{1}:\left(r_{21}\right)=0.471$ and $p_{\text {value }}=$ $0.000 \rightarrow p_{\text {value }}>0.05$. Based on these values, correlation coefficient between $x_{3}$ and $Y$ is significant. This means that although variable $x_{2}$ is well controlled, the leverage effect cause by $x_{2}$ remains significant to variable $Y$. Job factor leading to unsafe condition variable is still affecting the number of High potential occurrence.

Table 10 Partial correlation analysis variables $x 1$ and $Y$ by controlling variable $\times 2$

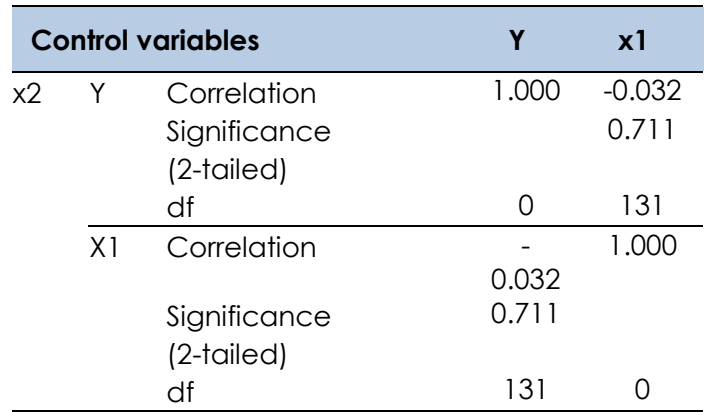

Table 11 Partial correlation analysis variables $X 2$ and $Y$ by controlling variable $\mathrm{xl}$

\begin{tabular}{|c|c|c|c|c|}
\hline \multicolumn{3}{|c|}{ Control variables } & \multirow{2}{*}{$\frac{Y}{1.000}$} & \multirow{2}{*}{$\frac{x 2}{0.471}$} \\
\hline $\mathrm{xl}$ & $Y$ & Correlation & & \\
\hline & & $\begin{array}{l}\text { Significance } \\
\text { (2-tailed) }\end{array}$ & & 0.000 \\
\hline & & df & 0 & 131 \\
\hline & \multirow[t]{3}{*}{$x 2$} & Correlation & 0.471 & 1.000 \\
\hline & & $\begin{array}{l}\text { Significance } \\
\text { (2-tailed) }\end{array}$ & 0.000 & \\
\hline & & df & 131 & 0 \\
\hline
\end{tabular}

The degree of importance respectively written as: $x_{1}\left(r_{12}\right)=-0.031$ and $x_{2}\left(r_{21}\right)=0.471$. Based on these values, variable $x_{2}$ is observed more significant compared to variable $x_{1}$.

\subsection{Path Analysis}

Path analysis is statistical methodology to evaluate causative relationship among two or more independent variables in corresponding to dependent variables [25]. Unlike regression analysis which can only evaluate direct relationship between variables, path analysis is capable to investigate indirect effect cause by intervening variables in the multiple causation models. High potential incident 
analysis is explained as causation model developed from inter-dependent root cause variables. Thus, path analysis is considered as suitable analytic tools to evaluate the problems in this research. Path analysis diagram (see Figure 10) and mathematical equation involved in this research is elaborated as follow:

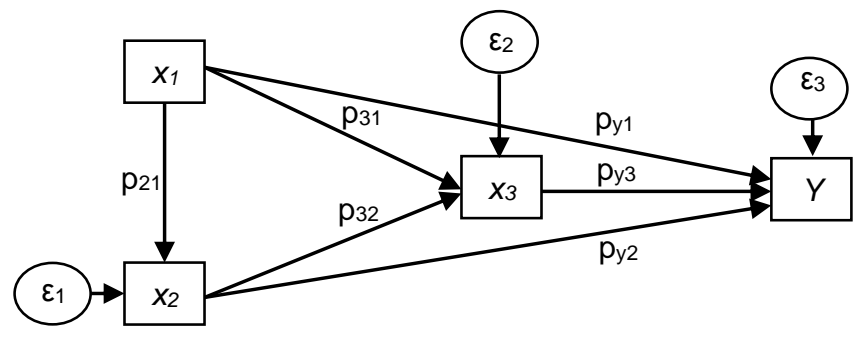

Figure 10 Path analysis diagram. It defines connection among variables $x 1, \times 2$, and $\times 3$

$$
\begin{gathered}
x_{2}=p_{21} x_{1}+\varepsilon_{1} \\
x_{3}=p_{31} x_{1}+p_{32} x_{2}+\varepsilon_{2} \\
Y=p_{y 1} x_{1}+p_{y 2} x_{2}+p_{y 3} x_{3}+\varepsilon_{3}
\end{gathered}
$$

Where, $p_{i j}$ are the path analysis coefficient which indicating the degree of importance for all variables towards variable $Y$. The value of $p_{i j}$ indicates the significance level of exogenous variables affecting endogenous variable. It is inferred that the significant value of incident root causes are represented by the value of $\mathrm{p}_{\mathrm{ij}}$. This research utilizes LISREL 8.80 software to simulate the path analysis. The result of path analysis is elaborated in Figure 11.

\begin{tabular}{|c|c|c|c|c|c|}
\hline \multirow{2}{*}{ Model } & \multicolumn{2}{|c|}{$\begin{array}{l}\text { Unstandardized } \\
\text { coefficients }\end{array}$} & \multirow{2}{*}{$\begin{array}{c}\begin{array}{c}\text { Standardized } \\
\text { coefficients }\end{array} \\
\text { Beta }\end{array}$} & \multirow[t]{2}{*}{$t$} & \multirow[t]{2}{*}{ Sig. } \\
\hline & B & $\begin{array}{l}\text { Std. } \\
\text { error }\end{array}$ & & & \\
\hline (Constant) & 6.636 & 1.002 & & 6.623 & 0.000 \\
\hline$x 1$ & 1.621 & 0.133 & 0.727 & 12.170 & 0.000 \\
\hline
\end{tabular}

Table 10 Path coefficient analysis by regression of variable $\mathrm{xl}$ from $\mathrm{xl}$ (structure 1)

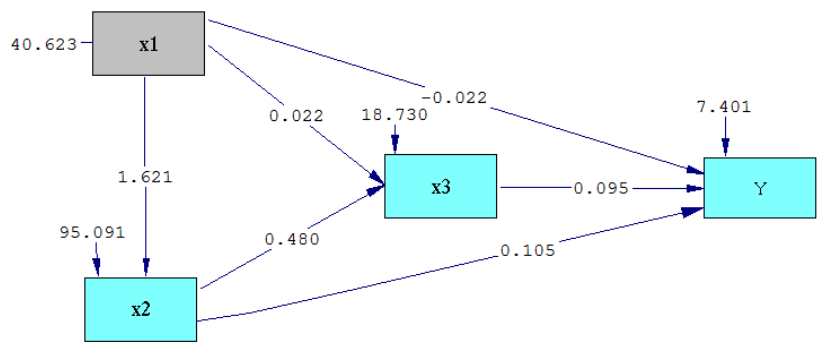

Figure 11 The result of Path analysis using LISREL 8.80 software
Therefore, the structural equation can be written as:

$$
\begin{gathered}
x_{2}=1.621 x_{1}+95.091 \\
x_{3}=0.022 x_{1}+0.480 x_{2}+18.730 \\
Y=-0.022 x_{1}+0.105 x_{2}+0.095 x_{3}+7.401
\end{gathered}
$$

Hence, the path coefficient values illustrated in Figurell need to be further tested by analyzing the breakdown structure. This effort is aimed to prove that this research analysis is statistically righteous.

Structure 1, pathway $\mathrm{x}_{1} \rightarrow \mathrm{x}_{2}$

Based on SPSS software simulation stated in Table 10, the obtained Path coefficient is 1.621 and the statistical values are:

$t_{\text {value }}=12.170, p_{\text {value }}=\frac{0.000}{2}=0.000 \rightarrow p_{\text {value }}<$ 0.05 (significant).

This means that variable Organizational factor $\left(x_{1}\right)$ is directly affecting variable job factor $\left(x_{2}\right)$ in positive linear correlation.

Structure 2, pathway $x_{1} \rightarrow x_{3}$ and $x_{2} \rightarrow x_{3}$

The analysis result for structure 2 is illustrated in Table 11. The statistical values are written as:

Model-: $\quad t_{\text {value }}=0.240 ; \quad p_{\text {value }}=\frac{0.804}{2}=0.402 \rightarrow$ $p_{\text {value }}>0.05$ (not significant).

From this analysis, it is inferred that variable Organizational factor $\left(x_{1}\right)$ is not significantly affecting variable Human factor $\left(x_{3}\right)$. Therefore, Model -1 is not acceptable to represent statistical relationship among all variables in the path analysis. The causation relationship shall be best described in Model-2.

Model-2: $t_{\text {value }}=18.358 ; p_{\text {value }}=\frac{0.000}{2}=0.000 \rightarrow$ $p_{\text {value }}<0.05$ (significant).

These statistical values inferred that variable Job factor $\left(x_{2}\right)$ is directly affecting variable Human factor $\left(x_{3}\right)$ in positive linear correlation.

Structure 3, pathway $x_{1} \rightarrow Y, x_{2} \rightarrow Y$, and $x_{3} \rightarrow Y$

Model-: $t_{\text {value }}=-0.412 ; \quad p_{\text {value }}=\frac{0.681}{2}=0.340 \rightarrow$ $p_{\text {value }}>0.05$ (right tailed test).

Based on these values, variable Organizational factor $\left(x_{1}\right)$ is not statistically significant to affect variable Number of High potential incident ( $Y$ ). Hence, Model-1 is not statistically proven as acceptable model.

Model-2: $t_{\text {value }}=3.105 ; \quad p_{\text {value }}=\frac{0.002}{2}=0.001 \rightarrow$ $p_{\text {value }}<0.05$ (significant) and $t_{\text {value }}=1.724 ; p_{\text {value }}=$ $\frac{0.087}{2}=0.0435 \rightarrow p_{\text {value }}<0.05$ (significant). 
Based on this test, variables Job ( $\left.x_{2}\right)$ and Human factors $\left(x_{3}\right)$ are directly affecting Number of High potential incident.

Table 11 Path coefficient analysis by regression of variable $x 3$ from $\times 2$ and $x 1$ (structure 2)

\begin{tabular}{|c|c|c|c|c|c|c|}
\hline & & \multicolumn{2}{|c|}{$\begin{array}{c}\text { Unstandardized } \\
\text { coefficients }\end{array}$} & $\begin{array}{l}\text { Standardized } \\
\text { coefficients }\end{array}$ & \multirow[b]{2}{*}{$t$} & \multirow[b]{2}{*}{ Sig. } \\
\hline \multicolumn{2}{|c|}{ Model } & B & $\begin{array}{l}\text { Std. } \\
\text { error }\end{array}$ & Beta & & \\
\hline \multirow[t]{3}{*}{1} & Constant & 0.514 & 0.515 & & 0.997 & 0.320 \\
\hline & $\mathrm{x} 1$ & 0.022 & 0.086 & 0.017 & 0.249 & 0.804 \\
\hline & $x 2$ & 0.480 & 0.039 & 0.835 & 12.376 & 0.000 \\
\hline \multirow[t]{2}{*}{2} & Constant & 0.508 & 0.513 & & 0.991 & 0.324 \\
\hline & $\times 2$ & 0.487 & 0.027 & 0.848 & 18.358 & 0.000 \\
\hline
\end{tabular}

Based on significance test performed on above process, this research eliminates the insignificant path coefficient to elaborate the adequate statistical model. Therefore, path analysis structure and equation need to be redeveloped. The final path analysis structure and equation is explained in Figure 12 and Equation (8) respectively. The path coefficient analysis is written in Table 12.

Table 12 Path coefficient analysis by regression of variable $Y$ from $\times 3, \times 2$ and $\times 1$ (structure 3 )

\begin{tabular}{|c|c|c|c|c|c|c|}
\hline & & \multicolumn{2}{|c|}{$\begin{array}{c}\text { Unstandardized } \\
\text { coefficients }\end{array}$} & $\begin{array}{c}\text { Standardized } \\
\text { coefficients }\end{array}$ & \multirow[b]{2}{*}{$t$} & \multirow[b]{2}{*}{ Sig. } \\
\hline \multicolumn{2}{|c|}{ Model } & B & $\begin{array}{l}\text { Std. } \\
\text { error }\end{array}$ & Beta & & \\
\hline \multirow[t]{4}{*}{1} & Constant & 3.270 & 0.326 & & 10.021 & 0.000 \\
\hline & $x 1$ & -0.022 & 0.055 & -0.042 & -0.412 & 0.681 \\
\hline & $\times 2$ & 0.105 & 0.036 & 0.435 & 2.916 & 0.004 \\
\hline & $\times 3$ & 0.095 & 0.055 & 0.226 & 1.727 & 0.087 \\
\hline \multirow[t]{3}{*}{2} & Constant & 3.276 & 0.325 & & 10.082 & 0.000 \\
\hline & $x 2$ & 0.098 & 0.032 & 0.406 & 3.105 & 0.002 \\
\hline & $x 3$ & 0.095 & 0.055 & 0.225 & 1.724 & 0.087 \\
\hline
\end{tabular}

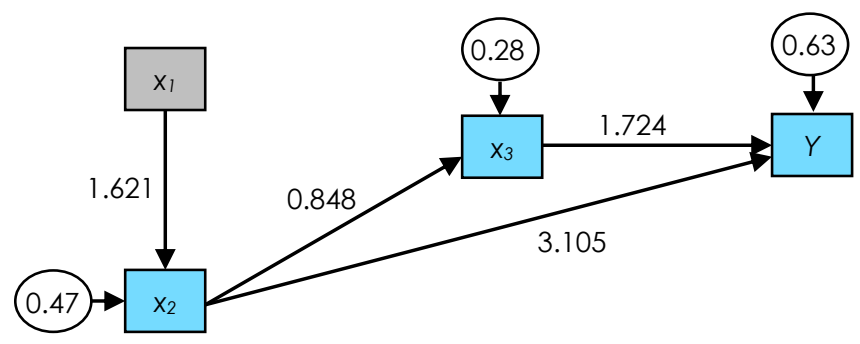

Figure 12 The result of path analysis in correspond to the test of significance

$$
\begin{gathered}
x_{2}=1.621 x_{1}+0.47 \\
x_{3}=0.848 x_{2}+0.28 \\
Y=3.105 x_{2}+1.724 x_{3}+0.63
\end{gathered}
$$

From Equation (8), it is concluded that the number of High potential incident is directly affected by Job factor leading to unsafe condition and Humanbehavioral factor. The degree of importance given by the equations implies that variable Humanbehavioral factor $(x 3)=1.724$ and Job factor leading to unsafe condition $(x 2)=3.105$. Whereas the variable Organizational factor does not directly affect the High potential incidents occurrence.

\subsection{CONCLUSION}

Based on the Pearson analysis, this research discloses the highest correlation between variable Job factor leading to unsafe working condition and Humanbehavioral factor $\left(x_{3}\right)=0.848$. It is concluded that the High potential incidents caused by Job factor are also caused by Human-behavioral factor. The relationship between the two variables is influencing each other. The Pearson Analysis also demonstrates that all variables have significant correlation, and this analysis leads to conclusion that the occurrence of High potential incidents is likely to be caused by multiple causative effect, or combination of the three causes.

From the multiple regression analysis with the degree of confidence of $95 \%$, it is inferred that the partial correlation coefficient value marks the degree of importance between variables. Therefore, variable $x_{2}\left(r_{23}=0.262\right)$ is more significant than variable $x_{3}\left(r_{32}=\right.$ $0.149)$. Whereas, the degree of importance comparison between $x_{1}$ and $x_{2}$ are written as: $x_{1}\left(r_{12}\right)=$ -0.031 and $x_{2}\left(r_{21}\right)=0.471$. Based on these values, variable $x_{2}$ is observed more significant compared to variable $x_{1}$.

Based on the path analysis result, the path equations' degree of importance demonstrates that variable Human-behavioral factor $\left(x_{3}\right)=1.724$ and Job factor leading to unsafe condition $\left(\mathrm{x}_{2}\right)=3.105$. Whereas the variable Organizational factor does not directly affect the High potential incidents occurrence.

The paper has demonstrated the implementation of regression analysis and path analysis for describing the structure and relationship of contributing factors to High potential incidents. Based on the analysis, it is concluded that the number of High potential incident is directly and significantly affected by Job factor leading to unsafe condition and Humanbehavioral factor. Although the Organizational system factor may not significantly affect the number of High potential incident, this factor still directly engenders unsafe working condition by affecting variable Job factor. Therefore, High potential incident correction and prevention should be addressed 
based on the degree of importance for each incident causes factor.

\section{Acknowledgement}

The authors of this research are grateful to the Andals Oil company for accessing their incident database as the main source of this research. This research does not received grants from any institution.

\section{References}

[1] J. E. Skogdalen and J. E. Vinnem. 2012. Combining Precursor Incidents Investigations and QRA in Oil and Gas Industry. Reliab. Eng. Syst. Saf. 101: 48-58.

Doi: 10.1016/j.ress.2011.12.009.

[2] D. K. H. Tang, F. Leiliabadi, E. U. Olugu, and S. Z. binti Md Dawal. 2017. Factors Affecting Safety of Processes in the Malaysian Oil and Gas Industry. Saf. Sci. 92: 44-52. Doi: 10.1016/j.ssci.2016.09.017.

[3] Ø. Dahl and E. Olsen. 2013. Safety Compliance on Offshore Platforms: A Multi-Sample Survey on the Role of Perceived Leadership Involvement and Work Climate. Saf. Sci. 54: 17-26. Doi: 10.1016/j.ssci.2012.11.003.

[4] F. D. Wicaksono. 2017. Implementation of Analytic Hierarchy Process for Determination of Incident Causes in Oil and Gas Industry. Proceeding, Indonesian Petroleum Association, Forty-First Annual Convention \& Exhibition. May.

[5] S. Z. Halim, S. Janardanan, T. Flechas, and M. S. Mannan. 2018. In Search of Causes Behind Offshore Incidents: Fire in Offshore Oil and Gas Facilities. J. Loss Prev. Process Ind. 54(April): 254-265.

Doi: 10.1016/j.jp.2018.04.006.

[6] U.S. Chemical Safety and Hazard Investigation Board. 2015. Final Investigation Report Chevron Richmond Refinery Pipe Rupture and Fire Chevron Richmond Refinery \#4 Crude Unit.

[7] D. A. Norman. 1981. Categorization of Action Slips. Psychol. Rev. 88(1): 1-15.

Doi: 10.1037/0033-295X.88.1.1.

[8] D. M. DeJoy. 1988. Human Factors Model of Workplace Accident Causation. Proc. Hum. Factors Soc. Annu. Meet. 32(15): 958-962.

Doi: $10.1518 / 107118188786761910$.

[9] P. L. Klumb. 1995. Cognitive Failures and Performance Differences: Validation Studies of a German Version of the Cognitive Failures Questionnaire. Ergonomics. 38(7): 14561467.

Doi: $10.1080 / 00140139508925202$.
[10] J. Rasmussen. 1997. Risk Management in a Dynamic Society: A Modelling Problem. Saf. Sci. 27(2/3): 183-213. Doi: 10.16250/j.32.1374.2016270.

[11] N. Leveson. 2004. A New Accident Model for Engineering Safer Systems. Saf. Sci. 42(4): 237-270. Doi: 10.1016/S0925-7535(03)00047-X.

[12] M. S. Mannan et al. 2005. The legacy of Bhopal: The Impact Over the Last 20 Years and Future Direction. J. Loss Prev. Process Ind. 18(4-6): 218-224. Doi: 10.1016/j.jp.2005.06.037.

[13] M. Christou and M. Konstantinidou. 2012. Safety of Offshore Oil and Gas Operations: Lessons from Past Accident Analysis. Publications Office of the EU. Doi: 10.2790/71887.

[14] J. E. Skogdalen, I. B. Utne, and J. E. Vinnem. 2011. Developing Safety Indicators for Preventing Offshore Oil and Gas Deepwater Drilling Blowouts. Saf. Sci. 49(8-9): $1187-1199$

Doi: 10.1016/j.ssci.2011.03.012.

[15] J. E. Vinnem, J. A. Hestad, J. T. Kvaløy, and J. E. Skogdalen. 2010. Analysis of Root Causes of Major Hazard Precursors (Hydrocarbon Leaks) in the Norwegian Offshore Petroleum Industry. Reliab. Eng. Syst. Saf. 95(11): 11421153 Doi: 10.1016/j.ress.2010.06.020.

[16] T. S. Abdelhamid and J. G. Everett. 2000. Identifying Root Causes of Construction Accidents. Jounal Constr. Eng. Manag. 52-80. Doi: 10.1061/(ASCE)0733-9364(2000)126:1 (52).

[17] OGP Report No. 444. 2011. Health \& Safety Incident Reporting System Users' Guide, 2010 Data.

[18] American Petroleum Institute. 2001. Recommended Practice for Design and Hazards Analysis for Offshore Production Facilities. United States of America. 1-75.

[19] American Petroleum Institute. 2016. Process Safety Performance Indicators for the Refining \& Petrochemical Industries. United States of America. 1-32.

[20] IOGP Report 2016su. 2017. Safety Data Reporting User's Guide - Scope and Definitions (2016 data). London.

[21] A. M. Herman and C. N. Jeffress. 2000. Process Safety Management. Washington DC, United States of America: U.S. Department of Labor, Occupational Safety and Health Administration. 1-53.

[22] I. Sutton. 2015. Process Risk and Reliability Management. Second Edi. Oxford: Elsevier Inc.

[23] K. Alkhaledi, S. Alrushaid, J. Almansouri, and A. Alrashed. 2015. Using Fault Tree Analysis in the Al-Ahmadi Town Gas Leak Incidents. Saf. Sci. 79: 184-192. Doi: 10.1016/j.ssci.2015.05.015.

[24] P. Di Lena and L. Margara. 2010. Optimal Global Alignment of Signals by Maximization of Pearson Correlation. Inf. Process. Lett. 110(1): 679-686. Doi: 10.1016/j.ipl.2010.05.024.

[25] Kadir. 2018. Statistika Terapan: Konsep, Contoh dan Analisis Data dengan Program SPSS/Lisrel dalam Penelitian. Depok: Rajawali Press. 